\title{
Perilaku Konsumen Terhadap Jajanan Tradisional di Kabupaten Pekalongan
}

\section{Consumer Behavior on Traditional Snacks in Pekalongan Regency}

\author{
Tjahja Muhandri $^{1,2) *}$, Uswatun Hasanah ${ }^{1,2)}$, dan Aisyah Amanah ${ }^{3)}$ \\ ${ }^{1)}$ Departemen Ilmu dan Teknologi Pangan, Fakultas Teknologi Pertanian, Institut Pertanian Bogor, Bogor \\ ${ }^{2)}$ South East Asian Food and Agricultural Sciences and Technology (SEAFAST) Center, Institut Pertanian Bogor, Bogor \\ ${ }^{3)}$ Program Sarjana, Fakultas Teknologi Pertanian, Institut Pertanian Bogor, Bogor
}

\begin{abstract}
Traditional snacks are made from local ingredients, cooked by boiling, steaming, frying, or grilling, whose recipes are passed down from predecessors throughout generations. This research was aimed to study consumer behavior in Pekalongan Regency towards traditional snacks and their preferences for traditional and modern snacks. This research was conducted with a survey method using the Google form online questionnaire to 100 respondens. Consumers of traditional snacks, both men and women, came from various ages, occupations, and income groups. The most popular and most consumed traditional snacks included getuk, nagasari, risol, klepon, bolang-baling, onde-onde, rengginang, rempeyek, putu, arem-arem, and apem. The majority of consumers bought traditional snacks at markets, street vendors, and food stalls. As many as 49\% of consumers often consumed traditional snacks with a frequency of 1-7 times a week. As many as 79\% of consumers from various age groups preferred traditional snacks because of its delicious and unique taste, affordable prices, natural ingredients, no preservatives, and preserving culture. As many as $29.51 \%$ of young consumers $(\leq 25$ years old) preferred modern snacks due to the simplicity, variations, easiness to get, attractiveness, and hygienic.
\end{abstract}

Keywords: consumer behavior, modern snacks, Pekalongan, tradisional snacks

\begin{abstract}
Abstrak. Jajanan tradisional adalah makanan ringan yang dibuat dari bahan-bahan lokal, dimatangkan dengan cara direbus, dikukus, digoreng, maupun dipanggang yang resepnya diwariskan oleh generasi pendahulu. Tujuan penelitian ini adalah mempelajari perilaku konsumen di Kabupaten Pekalongan dalam pembelian dan preferensi mereka terhadap jajanan tradisional maupun modern. Penelitian ini dilaksanakan dengan metode survei kepada 100 responden menggunakan kuesioner online Google Form. Konsumen jajanan tradisional, baik laki-laki maupun perempuan, memiliki keragaman karakteristik usia, pekerjaan, dan penghasilan. Hasil penelitian menunjukkan bahwa jajanan tradisional yang paling banyak diminati dan dikonsumsi antara lain getuk, nagasari, risol, klepon, bolang-baling, onde-onde, rengginang, rempeyek, putu, arem-arem, dan apem. Mayoritas konsumen membeli jajanan tradisional di pasar, pedagang keliling dan warung. Sebanyak 49\% konsumen tergolong sering mengonsumsi jajanan tradisional dengan frekuensi 1-7 kali seminggu. Sebanyak 79\% konsumen dari semua kelompok usia menyukai jajanan tradisional karena rasanya enak dan khas, harganya terjangkau, bahan bakunya alami, tanpa pengawet, sekaligus melestarikan budaya. Konsumen usia muda ( $\leq 25$ tahun) lebih menyukai makanan ringan modern $(29.51 \%)$ karena praktis, bervariasi, mudah didapat, menarik, dan higienis.
\end{abstract}

Kata kunci: jajanan tradisional, makanan ringan, Pekalongan, perilaku konsumen

Aplikasi Praktis. Perubahan perilaku konsumen dapat memengaruhi perubahan dalam konsumsi
produk. Riset ini berupaya mengungkap perilaku konsumen dalam membeli produk makanan jajanan
di Kabupaten Pekalongan. Hasil kajian di lapangan menunjukkan bahwa konsumen usia muda lebih
menyukai membeli makanan ringan modern dibandingkan jajanan tradisional. Hasil riset diharapkan
dapat menjadi data dasar bagi produsen makanan jajanan di Kabupaten Pekalongan untuk mem-
perbaiki mutu produk agar memenuhi keinginan konsumen, baik dari mutu sensori, maupun peng-
gunaan kemasan yang lebih praktis dan modern.

\section{PENDAHULUAN}

Makanan ringan adalah makanan yang dikonsumsi di antara tiga waktu makan utama setiap hari (Forbes et al. 2015). Kriteria utama dari makanan ringan adalah nyaman untuk dikonsumsi dan dapat memuaskan rasa lapar dalam waktu singkat. Jenis makanan ringan dapat berupa jajanan tradisional maupun makanan ringan modern.

Korespondensi: tjahjamuhandri@apps.ipb.ac.id 
Masyarakat Indonesia terbiasa mengonsumsi jajanan tradisional sebagai makanan selingan. Jajanan tradisional yang dibuat secara turun-temurun dan disajikan dengan sederhana menjadikan jajanan tradisional memiliki beberapa kelemahan seperti pengolahan yang tidak higienis, pengemasan yang kurang menarik, cita rasa yang kurang sesuai dengan selera generasi muda, dan umur simpan yang pendek (Giantara dan Santoso 2014). Suatu makanan dapat dinyatakan sebagai makanan tradisional apabila memenuhi beberapa aspek, yaitu dibuat dari bahan pangan yang diproduksi di daerah tertentu, diolah dengan cara yang dikuasai masyarakat daerah tersebut, memiliki cita rasa yang diterima dan dirindukan oleh masyarakat setempat, menjadi identitas kelompok masyarakat yang mengonsumsinya, dan menjadi identitas dari daerah tersebut (Aprile et al. 2012).

Makanan jajanan tradisional diduga dapat tergeser oleh makanan ringan modern. Makanan ringan modern adalah produk yang mudah dikonsumsi, rasanya enak, memiliki banyak bentuk, rasa, dan tekstur, serta memiliki umur simpan yang lama (Balentic et al. 2018). Produsen makanan ringan modern menggunakan beberapa bentuk teknologi sebagai dasar untuk membuat produk makanan ringan dan juga meningkatkan daya tarik produk yang dihasilkan. Konsumen usia muda diduga lebih tertarik pada makanan ringan modern dibandingkan dengan jajanan tradisional. Kondisi ini diduga juga berlangsung di Kabupaten Pekalongan.

Penelitian ini bertujuan untuk mempelajari perilaku konsumen jajanan tradisional di Kabupaten Pekalongan terutama untuk mengidentifikasi karakteristik konsumen, jenis produk jajanan tradisional yang sering dikonsumsi, jenis produk jajanan tradisional yang paling disukai, alasan konsumen menyukai atau tidak menyukai jajanan tradisional, serta lokasi pembelian dan frekuensi konsumsi. Penelitian ini juga mempelajari perbandingan ketertarikan konsumen terhadap jajanan tradisional dan modern.

\section{BAHAN DAN METODE}

\section{Bahan}

Bahan yang digunakan dalam penelitian ini adalah data yang dikumpulkan dengan menyebarkan kuesioner online menggunakan google form.

Populasi dan sampel penelitian (Fransisca et al. 2016)

Populasi penelitian ini adalah penduduk Kabupaten Pekalongan. Berdasarkan data Badan Pusat Statistik Kabupaten Pekalongan (2020) jumlah penduduk Kabupaten Pekalongan adalah sebanyak 897.711 orang. Ukuran sampel sebanyak 100 responden, yang ditentukan dengan rumus Slovin (Fransisca et al. 2016). Rumus Slovin digunakan untuk menentukan minimal ukuran sampel apabila ukuran populasi diketahui dan distribusi populasi diasumsikan normal. Perhitungan ukuran sampel dengan tingkat kepercayaan $90 \%$ adalah sebagai berikut:

$$
\begin{gathered}
n=\frac{N}{1+N \cdot e^{2}} \ldots \ldots \ldots \\
n=\frac{897711}{1+897711(0.1)^{2}} \\
n=99.9 \approx 100 \ldots \ldots
\end{gathered}
$$

keterangan: $\mathrm{n}=$ ukuran sampel; $\mathrm{N}=$ ukuran populasi; $\mathrm{e}=$ toleransi ketidaktelitian ( $10 \%$ pada tingkat kepercayaan $90 \%)$.

\section{Penyusunan dan pengujian kuesioner (Siregar 2017)}

Kuesioner terbagi menjadi dua bagian yaitu data diri dan perilaku konsumen. Bagian data diri terdiri dari 10 pertanyaan dan bagian perilaku konsumen terdiri dari 10 pertanyaan. Jenis pertanyaan dalam kuesioner ini adalah pertanyaan terbuka (jawaban isian) dan pertanyaan tertutup (terdapat pilihan jawaban).

Uji reliabilitas kuesioner dilakukan untuk mengetahui apakah kuesioner yang disusun merupakan alat pengumpul data yang baik. Kuesioner yang telah dibuat diuji coba pada responden yang sama sebanyak dua kali pada waktu yang berbeda. Rentang waktu pengukuran pertama dan kedua adalah 30 hari. Hal tersebut bertujuan untuk menghindari responden yang masih mengingat jawaban pada pengukuran pertama. Responden yang digunakan berjumlah 30 orang agar distribusi skor mendekati kurva normal. Hasil uji coba selanjutnya diolah dengan teknik product moment, yaitu mengorelasikan nilai $r_{\text {hitung dengan }} r_{\text {tabel }}$. Rumus menentukan $\mathrm{r}_{\text {hitung }}$ adalah sebagai berikut:

$$
r_{\text {hitung }}=\frac{n(\Sigma X Y)-(\Sigma X)(\Sigma Y)}{\sqrt{\left[n\left(\Sigma X^{2}\right)-(\Sigma X)^{2}\right]\left[n\left(\Sigma Y^{2}\right)-(\Sigma Y)^{2}\right]}}
$$

keterangan: $\mathrm{X}=$ skor total pengukuran pertama; $\mathrm{Y}=$ skor total pengukuran kedua; $n=$ jumlah responden.

Kuesioner dinyatakan reliabel jika hasil pengukuran pertama dan kedua konsisten, yaitu apabila koefisien korelasi $r_{\text {hitung }}$ lebih besar dari $r_{\text {tabel }}$. Uji reliabilitas menunjukkan bahwa nilai $r_{\text {hitung }}$ adalah 0.648 , sedangkan nilai $r_{\text {tabel }}$ pada tingkat kepercayaan $95 \%$ adalah 0.361 . Nilai $r_{\text {hitung }}$ lebih besar dari $r_{\text {tabel }}$ sehingga kuesioner dapat dinyatakan reliabel.

\section{Metode penetapan responden (Siregar 2017)}

Metode penetapan responden yang digunakan adalah disproportionate stratified random sampling. Metode ini digunakan apabila populasi memiliki strata atau tingkatan yang jumlahnya tidak proporsional. Metode ini dilakukan dengan mengelompokkan populasi menurut jenisnya, kemudian masing-masing kelompok ini ditentukan porsinya dengan tidak berimbang sesuai jumlah yang ada.

Kriteria sampel yang diambil adalah minimal berusia 13 tahun atau setara dengan siswa kelas 1 SMP. Siswa SMP merupakan sampel yang diasumsikan memiliki alat komunikasi dan dapat mengisi sendiri 
kuesioner secara online. Kuesioner disebarkan secara acak kemudian diambil responden pada masing-masing kelompok usia untuk memenuhi ukuran sampel 100 orang. Jumlah responden berdasarkan rentang usia adalah 25 orang (usia 13-17 tahun), 36 orang (usia 18-25 tahun), 14 orang (usia 26-35 tahun), dan 25 orang (usia lebih dari 35 tahun).

\section{Analisis data (Siregar 2017)}

Metode analisis data yang dilakukan adalah analisis deskriptif kuantitatif menggunakan program microsoft excel 2010. Analisis deskriptif dilakukan dengan cara memberikan gambaran umum atas kondisi atau variabelvariabel penelitian. Contoh pendeskripsian data yang paling sering adalah menghitung frekuensi atribut hasil penilaian responden.

\section{HASIL DAN PEMBAHASAN}

\section{Karakteristik konsumen jajanan tradisional}

Survei penelitian ini dilakukan terhadap 100 responden yang pernah mengonsumsi jajanan tradisional. Karakteristik responden yang ditanyakan tergolong karakteristik demografi, yaitu karakteristik berdasarkan ilmu kependudukan seperti usia, jenis kelamin, pekerjaan, pendidikan, dan penghasilan. Karakteristik responden tersebut dapat dilihat pada Tabel 1.

Memahami karakteristik konsumen merupakan langkah dalam menentukan segmentasi pasar. Adnan (2018) menyatakan bahwa faktor budaya, sosial, dan psikologis dari konsumen, berpengaruh signifikan terhadap keputusan pembelian. Penelitian Yulianti (2011) menunjukkan bahwa faktor usia, pendidikan dan jenis pekerjaan merupakan faktor utama dalam mempertimbangkan keputusan pembelian.

Berdasarkan Tabel 1 dapat diketahui bahwa konsumen jajanan tradisional baik laki-laki (44\%) maupun perempuan $(56 \%)$ berasal dari berbagai kelompok usia, pekerjaan, dan penghasilan. Jumlah responden tidak menggambarkan jumlah konsumen jajanan tradisional pada kondisi sebenarnya, melainkan menggambarkan keterjangkauan survei penelitian ini. Segmentasi pasar jajanan tradisional yang sesuai dengan karakteristik responden tersebut adalah konsumen semua kalangan atau umum, yaitu laki-laki maupun perempuan dan dari berbagi usia.

\section{Karakteristik produk jajanan tradisional}

Jajanan tradisional memiliki variasi produk yang sangat beragam, baik dari bahan baku maupun proses pembuatan. Penelitian ini mengidentifikasi apa saja produk jajanan tradisional diantara variasi tersebut yang paling sering dan paling disukai oleh konsumen. Konsumen akan cenderung sering membeli produk yang mereka sukai. Konsumen yang membeli suatu produk dengan frekuensi berulang kali secara rutin disebut sebagai pelanggan. Produk yang paling sering dikonsumsi menunjukkan bahwa produk tersebut sudah memiliki pelanggan.

Tabel 1. Karakteristik konsumen jajanan tradisional

\begin{tabular}{|c|c|c|}
\hline Karakteristik & Jumlah (Orang) & Persentase (\%) \\
\hline \multicolumn{3}{|l|}{ Jenis Kelamin } \\
\hline Laki-laki & 44 & 44.00 \\
\hline Perempuan & 56 & 56.00 \\
\hline Total & 100 & 100.00 \\
\hline \multicolumn{3}{|l|}{ Usia (tahun) } \\
\hline $13-17$ & 25 & 25.00 \\
\hline $18-25$ & 36 & 36.00 \\
\hline $26-35$ & 14 & 14.00 \\
\hline$\geq 36$ & 25 & 25.00 \\
\hline Total & 100 & 100.00 \\
\hline \multicolumn{3}{|l|}{ Sudah bekerja } \\
\hline \multicolumn{3}{|l|}{ Pekerjaan } \\
\hline Pegawai negeri & 18 & 18.00 \\
\hline Pegawai swasta & 13 & 13.00 \\
\hline Pegawai non PNS & 4 & 4.00 \\
\hline Wiraswasta & 2 & 2.00 \\
\hline Pedagang & 2 & 2.00 \\
\hline Buruh & 1 & 1.00 \\
\hline Total & 40 & 40.00 \\
\hline \multicolumn{3}{|c|}{ Penghasilan per bulan (Rp) } \\
\hline$<1.500 .000$ & 6 & 6.00 \\
\hline $1.500 .000-3.000 .000$ & 9 & 9.00 \\
\hline$>3.000 .000$ & 25 & 25.00 \\
\hline Total & 40 & 40.00 \\
\hline \multicolumn{3}{|l|}{ Belum/Tidak bekerja } \\
\hline \multicolumn{3}{|l|}{ Status } \\
\hline Siswa SMP & 4 & 4.00 \\
\hline Siswa SMA/SMK & 20 & 20.00 \\
\hline Mahasiswa & 32 & 32.00 \\
\hline Ibu rumah tangga & 4 & 4.00 \\
\hline Total & 60 & 60.00 \\
\hline \multicolumn{3}{|l|}{ Uang saku per hari (Rp) } \\
\hline$<10.000$ & 10 & 10.00 \\
\hline $10.000-30.000$ & 44 & 44.00 \\
\hline$>30.000$ & 6 & 6.00 \\
\hline Total & 60 & 60.00 \\
\hline
\end{tabular}

Tabel 2 menunjukkan 10 produk jajanan tradisional yang paling sering dikonsumsi, sedangkan Tabel 3 menunjukkan 10 produk jajanan tradisional yang paling disukai. Berdasarkan Tabel 2 dan 3 dapat diketahui bahwa 9 dari 10 produk jajanan tradisional merupakan produk yang paling sering dikonsumsi sekaligus disukai oleh konsumen. Bolang-baling termasuk 10 jajanan yang sering dikonsumsi namun tidak termasuk 10 jajanan yang paling disukai. Apem termasuk 10 jajanan yang paling disukai namun tidak termasuk 10 jajanan yang sering dikonsumsi. Produk-produk tersebut merupakan jajanan tradisional yang dapat menjadi peluang pasar bagi pelaku usaha.

Studi segmentasi pasar bertujuan untuk menemukan kebutuhan dan keinginan kelompok konsumen tertentu. Berdasarkan informasi tersebut, perusahaan dapat mengembangkan produk yang dapat memuaskan kebutuhan dan keinginan konsumen. Perusahaan yang menerapkan pemasaran segmen memahami bahwa konsumen memiliki selera yang berbeda-beda. Perusahaan membagi pasar menjadi sekelompok pembeli yang memiliki keinginan homogen atau seragam, kemudian menawarkan produk yang sesuai dengan keinginan dan selera pasar target (Sumarwan dan Tjiptono 2018). Hal-hal 
yang disukai konsumen terhadap suatu produk dapat menggambarkan selera konsumen.

Tabel 2. Produk jajanan tradisional yang paling sering dikonsumsi

\begin{tabular}{lc}
\hline \multicolumn{1}{c}{ Nama } & Jumlah Responden (Orang) \\
\hline Getuk & 33 \\
Nagasari & 27 \\
Risol & 26 \\
Klepon & 23 \\
Bolang-baling & 23 \\
Onde-onde & 21 \\
Rengginang & 18 \\
Rempeyek & 17 \\
Putu & 17 \\
Arem-arem & 15 \\
\hline Keterangan: ${ }^{*}$ responden dapat memilih lebih dari 1
\end{tabular}

Tabel 3. Produk jajanan tradisional yang paling disukai

\begin{tabular}{lc}
\hline \multicolumn{1}{c}{ Nama } & Jumlah Responden (Orang) $^{\star}$ \\
\hline Klepon & 30 \\
Getuk & 28 \\
Risol & 20 \\
Nagasari & 18 \\
Putu & 15 \\
Onde-onde & 15 \\
Arem-arem & 12 \\
Apem & 12 \\
Rengginang & 10 \\
Rempeyek & 9 \\
\hline Keterangan: ${ }^{*}$ responden dapat memilih lebih dari 1
\end{tabular}

Alasan konsumen menyukai jajanan tradisional dapat dilihat pada Tabel 4. Berdasarkan Tabel 4 dapat diketahui bahwa konsumen menyukai jajanan tradisional karena rasa yang enak $(n=92)$, harga yang terjangkau $(n=65)$, mudah didapat $(n=54)$, kandungan gizi $(n=25)$, penampilan yang menarik $(n=12)$, dan mengenyangkan $(n=5)$. Hasil penelitian ini sejalan dengan studi perilaku konsumen terhadap jajanan tradisional di Surakarta yang menunjukkan bahwa harga, kualitas, dan kemudahan mendapatkan produk memengaruhi sikap positif terhadap produk dan intensitas untuk membeli (Haryanto et al. 2019). Pelaku usaha dapat memilih salah satu kriteria untuk dijadikan segmen pasar atau mengembangkan produk yang memenuhi semua kriteria tersebut.

Tabel 4. Alasan konsumen menyukai jajanan tradisional

\begin{tabular}{lc}
\hline \multicolumn{1}{c}{ Kriteria } & Jumlah Responden (Orang) \\
\hline Rasa enak & 92 \\
Harga terjangkau & 65 \\
Mudah didapat & 54 \\
Kandungan gizi & 25 \\
Penampilan menarik & 12 \\
Mengenyangkan & 5 \\
\hline Kenan
\end{tabular}

Keterangan: ${ }^{*}$ responden dapat memilih lebih dari 1

Keunggulan produk terbukti secara jelas banyak disukai konsumen. Semakin konsumen mengetahui keunggulan dari produk, maka konsumen akan menentukan keputusan pembelian terhadap produk tersebut. Produsen biasanya menambahkan atribut pada produknya dengan melengkapi manfaat atau hal lain yang dapat meningkatkan keunggulan produknya sehingga memengaruhi perilaku konsumen.

Kelemahan dari jajanan tradisional disajikan pada Tabel 5. Berdasarkan Tabel 5 dapat diketahui bahwa mayoritas konsumen menganggap jajanan tradisional tidak tahan lama $(n=81)$. Hasil penelitian ini sejalan dengan studi konsumen Blum et al. (2019) yang menyatakan bahwa konsumen usia 16-19 tahun mempersepsikan jajanan tradisional sebagai jajanan yang mudah mengalami penurunan kualitas dan kurang lezat. Jajanan tradisional terbuat dari bahan alami dan tanpa pengawet sehingga hanya bertahan 12-24 jam, sedangkan jajanan yang kering mampu bertahan hingga 7-12 hari. Sebagian konsumen juga beranggapan bahwa jajanan tradisional sulit didapat $(\mathrm{n}=31)$. Hal tersebut disebabkan ketersediaan jajanan tradisional di pasaran saat ini semakin berkurang dibandingkan saat makanan ringan modern belum beredar luas.

Tabel 5. Kelemahan jajanan tradisional menurut konsumen

\begin{tabular}{lc}
\multicolumn{1}{c}{ Kriteria } & Jumlah Responden (Orang) $^{*}$ \\
\hline Tidak tahan lama & 81 \\
Sulit didapat & 31 \\
Penampilan tidak menarik & 27 \\
Kurang higienis & 16 \\
Kurang Praktis & 9 \\
Kuno & 5 \\
\hline Keterangan: ${ }^{*}$ responden dapat memilih lebih dari 1
\end{tabular}

Jajanan tradisional dianggap penampilannya tidak menarik $(n=27)$ dan kurang praktis $(n=9)$ disebabkan pengemasan jajanan tradisional yang masih sederhana. Bahan yang biasanya digunakan untuk mengemas jajanan tradisional adalah kertas, daun, dan bambu (Noviadji 2014). Beberapa jenis produk jajanan tradisional sudah menggunakan plastik sebagai kemasan, namun plastik yang digunakan bentuknya monoton dan kurang informatif sehingga tidak menarik perhatian konsumen (Amelia 2017). Jajanan tradisional dianggap kurang higienis $(n=16)$ karena penanganannya sering tidak bersih dan pedagang kurang patuh terhadap penerapan Cara Produksi Pangan Olahan yang Baik (Komalasari dan Widiawati 2020).

Kelemahan dari sebuah produk dapat dijadikan sebagai peluang oleh produsen untuk mengembangkan produk yang mengatasi kelemahan tersebut, sehingga produk tersebut memiliki nilai tambah dibandingkan produk yang lain. Berdasarkan kelemahan jajanan tradisional yang disebutkan sebelumnya, produsen memiliki peluang untuk mengembangkan jajanan tradisional yang tahan lama, dapat dipasarkan secara luas, kemasannya menarik dan praktis, dan keamanannya terjamin.

\section{Perilaku konsumen jajanan tradisional}

\section{Frekuensi Konsumsi}

Frekuensi konsumsi konsumen jajanan tradisional berdasarkan usia dapat dilihat pada Tabel 6. Berdasarkan Tabel 6 dapat diketahui bahwa mayoritas konsumen mengonsumsi jajanan tradisional dengan frekuensi 1-7 kali seminggu, yaitu sebanyak 49\%. Hal tersebut menunjukkan bahwa tingkat konsumsi jajanan tradisional di Kabupaten Pekalongan tergolong tinggi. Konsumen cenderung hampir setiap hari mengonsumsi jajanan tradisional, sehingga terdapat peluang yang cukup besar bagi pelaku usaha untuk menjual jajanan tradisional. 
Berdasarkan Tabel 6, maka dapat diketahui juga bahwa konsumen yang sangat sering mengonsumsi jajanan tradisional hanya yang berusia $\geq 36$ tahun, yang merupakan kelompok usia tertua. Kelompok usia tertua lebih terbiasa mengonsumsi jajanan tradisional karena dahulu belum banyak beredar makanan ringan modern, sehingga mereka cenderung lebih menyukai jajanan tradisional. Makanan tradisional termasuk makanan ringan dapat diklasifikasikan sebagai produk yang dibuat dengan cara tertentu, dikenal karena sifat sensorinya, dan berkaitan dengan area, wilayah, atau negara tertentu (Balogh et al. 2016).

Konsumen yang jarang mengonsumsi jajanan tradisional, hanya yang berusia 18-25 tahun. Kelompok usia tersebut mayoritas berstatus sebagai mahasiswa dan merantau ke luar kota, sehingga mereka hanya dapat mengonsumsi jajanan tradisional Pekalongan ketika pulang ke Pekalongan.

\section{Lokasi pembelian}

Konsumen tidak selalu mengonsumsi jajanan tradisional dengan membelinya terlebih dahulu, melainkan juga dari rumah, baik dibuat sendiri atau anggota keluarga maupun diperoleh dari acara tertentu. Berdasarkan Tabel 7 dapat diketahui bahwa konsumen yang mengonsumsi jajanan tradisional dari rumah maupun acara adat memiliki jumlah yang hampir sama, yaitu 34 dan 33 orang. Hal ini menunjukkan bahwa masyarakat Kabupaten Pekalongan masih memiliki minat untuk membuat sendiri jajanan tradisional baik untuk konsumsi sendiri maupun untuk keperluan acara adat tertentu, meskipun dari segi jumlah tidak begitu banyak. Kegiatan tersebut dapat menggambarkan motivasi masyarakat Kabupaten Pekalongan untuk tetap melestarikan jajanan tradisional.

Berdasarkan Tabel 7 dapat diketahui juga bahwa mayoritas konsumen membeli jajanan tradisional dari pasar $(n=65)$, pedagang keliling $(n=61)$, dan warung $(\mathrm{n}=54)$, sedangkan hanya sedikit konsumen yang membeli dari Pasar Rindu Semilir $(n=13)$. Pasar Rindu Semilir merupakan pasar kuliner tradisional khas Jawa yang terletak di area hutan kota, Alun-alun Kabupaten Pekalongan. Pasar Rindu Semilir diresmikan oleh Bupati Kabupaten Pekalongan pada tahun 2019 dengan tujuan membuka tempat wisata keluarga yang murah, menyajikan jajanan tradisional yang sudah jarang ditemui, dan memberdayakan usaha mikro, kecil, dan menengah (UMKM).

Kurangnya konsumen yang membeli jajanan tradisional di Pasar Rindu Semilir dapat disebabkan oleh dua faktor. Faktor yang pertama yaitu Pasar Rindu Semilir hanya dibuka pada hari Minggu, sehingga konsumen tidak dapat berkunjung pada hari kerja. Faktor yang kedua adalah Pasar Rindu Semilir hanya terletak di satu lokasi saja, yaitu di Kecamatan Kajen. Masyarakat yang berasal dari kecamatan lain, terutama kecamatan yang jauh dari Kecamatan Kajen, akan membutuhkan usaha lebih untuk berkunjung ke Pasar Rindu Semilir, sehingga Pasar Rindu Semilir diperuntukkan bagi konsumen yang ingin berwisata sekaligus. Kabupaten Pekalongan memiliki banyak tempat wisata di berbagai kecamatan, sehingga dapat dijadikan alternatif bagi Pemerintah Kabupaten Pekalongan untuk membuka cabang Pasar Rindu Semilir agar semakin luas menjangkau masyarakat. Tempat pembelian yang menarik dan lokasi yang strategis, misalnya di pasar modern dapat memengaruhi penjualan makanan tradisional di Kota Malang (Yulianti 2011) dan di Yogyakarta (Khairullah 2020).

Tabel 7. Lokasi pembelian jajanan tradisional

\begin{tabular}{lc}
\hline \multicolumn{1}{c}{ Lokasi } & Jumlah Responden (Orang) \\
\hline Pasar & 63 \\
Pedagang keliling & 61 \\
Warung & 54 \\
Rumah & 34 \\
Acara adat & 33 \\
Pasar Rindu Semilir & 13 \\
\hline
\end{tabular}

Keterangan: ${ }^{*}$ responden dapat memilih lebih dari 1

\section{Faktor-faktor yang memengaruhi keputusan konsumsi}

Konsumen akan melakukan pertimbangan terlebih dahulu sebelum melakukan pengambilan keputusan atau pembelian suatu produk. Faktor yang memengaruhi keputusan konsumsi jajanan tradisional disajikan pada Tabel 8. Faktor yang paling banyak memengaruhi konsumen untuk mengonsumsi jajanan tradisional adalah atribut rasa, dengan tingkat pengaruh paling tinggi, yaitu sebesar 6.02. Jajanan tradisional memiliki rasa yang khas sehingga atribut rasa merupakan faktor yang paling diutamakan konsumen. Hal ini sejalan dengan penelitian Casini et al. (2016) yang menyatakan bahwa faktor asal (origin) paling memengaruhi pembelian makanan tradisional.

Atribut harga juga banyak memengaruhi konsumen, namun tingkat pengaruhnya (sebesar 4.99) lebih rendah dari atribut kepuasan konsumsi sebelumnya (sebesar 5.25) dan kebersihan (sebesar 5.16). Hal tersebut menunjukkan bahwa konsumen lebih memerhatikan atribut kebersihan dan kepuasan konsumsi sebelumnya dibandingkan harga dari jajanan tradisional, karena jajanan tradisional pada dasarnya memiliki harga yang terjangkau. Hasil penelitian ini menjadi catatan penting bagi pelaku usaha agar selalu memerhatikan kualitas produk, terutama rasa dan kebersihan.

Tabel 6. Frekuensi konsumsi konsumen jajanan tradisional berdasarkan usia

\begin{tabular}{|c|c|c|c|c|c|c|}
\hline \multirow{2}{*}{ Frekuensi Konsumsi } & \multicolumn{4}{|c|}{ Usia (Tahun) } & \multirow{2}{*}{ Total } & \multirow{2}{*}{ Persentase (\%) } \\
\hline & 13-17 & 18-25 & $26-35$ & $\geq 36$ & & \\
\hline Sangat sering (> 7 kali seminggu) & - & - & - & 3 & 3 & 3.00 \\
\hline Sering (1-7 kali seminggu) & 12 & 14 & 9 & 14 & 49 & 49.00 \\
\hline Kadang-kadang (1-3 kali sebulan) & 13 & 19 & 5 & 8 & 45 & 45.00 \\
\hline Jarang ( $\geq 2$ kali setahun) & - & 3 & - & - & 3 & 3.00 \\
\hline Sangat jarang ( $\leq 1$ kali setahun) & - & - & - & - & 0 & 0.00 \\
\hline Total & 25 & 36 & 14 & 25 & 100 & 100.00 \\
\hline
\end{tabular}


Kondisi ini berbeda dengan perilaku konsumen di Kota Malang, faktor harga merupakan pertimbangan utama untuk menentukan pembelian (Yulianti 2011). Di sisi lain, makanan ringan modern seperti keripik kentang cenderung tergolong low involvement product berdasarkan pengalaman terhadap kualitas pembelian sebelumnya (Zbib et al. 2010).

Tabel 8. Faktor yang memengaruhi keputususan konsumsi jajanan tradisional

\begin{tabular}{|c|c|c|}
\hline Atribut & $\begin{array}{c}\text { Jumlah Responden } \\
\text { (orang) }^{*}\end{array}$ & $\begin{array}{c}\text { Tingkat } \\
\text { Pengaruh }^{a}\end{array}$ \\
\hline Rasa & 95 & 6.02 \\
\hline Harga & 66 & 4.99 \\
\hline Kepuasan konsumsi & & 5.25 \\
\hline sebelumnya & 35 & \\
\hline Kebutuhan (rasa lapar) & 34 & 4.44 \\
\hline Nostalgia & 28 & 4.63 \\
\hline Kebersihan & 20 & 5.16 \\
\hline Penampilan & 16 & 4.58 \\
\hline Lokasi & 9 & 4.56 \\
\hline Kecepatan pelayanan & 1 & 4.64 \\
\hline eterangan: *responden & oat $n$ & $1 ;{ }^{a} s$ \\
\hline
\end{tabular}

Berdasarkan Tabel 8 dapat diketahui juga bahwa atribut kebutuhan memengaruhi konsumen dengan jumlah yang hampir sama dengan atribut kepuasan konsumsi namun memiliki tingkat pengaruh yang paling rendah, yaitu sebesar 4.44. Hal tersebut dapat terjadi karena konsumen merasa jajanan tradisional dapat mengenyangkan, namun sebelum itu konsumen akan menilai rasa, harga, maupun faktor lain yang lebih berpengaruh. Sebagian konsumen dipengaruhi atribut nostalgia dengan tingkat pengaruh sebesar 4.63 , yang lebih rendah dari atribut harga (sebesar 4.99). Hal ini menunjukkan bahwa konsumen memiliki motivasi untuk mengenang masa lalu dengan cara mengonsumsi jajanan tradisional. Atribut penampilan, lokasi, dan kecepatan pelayanan memengaruhi sedikit konsumen, dengan tingkat pengaruh yang hampir setara, yaitu berturut-turut sebesar 4.58, 4.56, dan 4.64 .

\section{Preferensi konsumen terhadap jajanan tradisional dan modern}

Studi yang dilakukan oleh Favalli et al. (2013) tentang perbandingan makanan tradisional dan modern menunjukkan bahwa kombinasi penampilan dan tekstur sangat memengaruhi pemahaman konseptual keseluruhan produk makanan tersebut. Kaum muda lebih memahami makanan modern karena pengaruh iklan di media sosial atau internet.

Preferensi konsumen terhadap jajanan tradisional dan modern berdasarkan usia disajikan pada Tabel 9. Sebanyak 79\% konsumen dari berbagai kelompok usia lebih menyukai jajanan tradisional dibandingkan jajanan modern. Konsumen tersebut lebih menyukai jajanan tradisional karena jajanan tradisional memiliki rasa yang enak dan khas, memiliki harga yang terjangkau, menggunakan bahan alami, tanpa menggunakan pengawet, tanpa menggunakan BTP, menyehatkan, nostalgia dan melestarikan budaya. Hal ini menunjukkan bahwa konsumen memandang jajanan tradisional lebih aman karena menggunakan bahan alami dan tidak menggunakan BTP berdasarkan resep pembuatannya yang sudah umum diketahui, meskipun tidak ada jaminan keamanan yang melekat pada produk yang beredar di pasaran.

Perbedaan yang cukup nyata ditemukan pada kelompok usia yang berbeda. Sebanyak 18 dari 61 (29.51\%) konsumen usia muda $(\leq 25$ tahun) lebih menyukai jajanan modern. Hal ini berbeda dengan kelompok usia di atas 26 tahun, hanya 3 dari 39 (7.69\%) konsumen yang menyukai jajanan modern. Hasil penelitian ini menguatkan studi sebelumnya oleh Blum et al. (2019) yang menyatakan bahwa perempuan usia 16-19 tahun di 5 kota besar di Pulau Jawa, Indonesia, lebih banyak mengonsumsi jajanan modern dibandingkan jajanan tradisional. Terjadi pergeseran tingkat kesukaan pada usia muda, mengarah pada jajanan modern. Konsumen muda menyukai makanan ringan modern karena mudah didapat, praktis, bervariasi, menarik, enak, dan higienis. Hampir semua makanan ringan modern dapat diakses secara online (Sidharta dan Sidh 2014).

Pelaku usaha yang ingin menargetkan konsumen dari kelompok usia muda perlu mengembangkan variasi produk, salah satunya berkaitan dengan rasa. Rasa pada jajanan tradisional didominasi oleh rasa manis gula merah maupun rasa gurih dari santan, sehingga perlu dikembangkan dengan rasa baru agar lebih bervariasi. Pelaku usaha juga perlu mengembangkan tampilan yang lebih menarik seperti yang disajikan di hotel atau restoran, mengembangkan kemasan yang praktis dan menarik, serta menjaga higienitas jajanan tradisional. Hal tersebut dapat dicapai dengan cara memperbaiki kemasan jajanan tradisional yang mayoritas menggunakan daun pisang maupun plastik transparan.

\section{KESIMPULAN}

Konsumen jajanan tradisional, baik laki-laki maupun perempuan, berasal dari berbagai kelompok usia, pekerjaan, maupun penghasilan, sehingga segmentasi pasar yang sesuai adalah konsumen dari berbagai kalangan atau umum. Jajanan tradisional yang paling banyak diminati dan dikonsumsi antara lain getuk, nagasari, risol, klepon, bolang-baling, onde-onde, rengginang, rempeyek, putu, arem-arem, dan apem. Produkproduk tersebut dapat dijadikan acuan bagi pelaku usaha sebagai jenis jajanan tradisional yang akan diproduksi. Mayoritas konsumen menyukai jajanan tradisional karena rasanya yang enak, harganya terjangkau, dan mudah di dapat. Kelemahan jajanan tradisional menurut konsumen antara lain tidak tahan lama, penampilannya tidak menarik, dan kurang higienis. Lokasi yang dominan dipilih konsumen untuk membeli jajanan tradisional adalah pasar, pedagang keliling dan warung. Sebagian masyarakat Kabupaten Pekalongan memiliki minat untuk membuat sendiri jajanan tradisional baik untuk konsumsi sendiri atau keperluan acara adat. 
Tabel 9. Preferensi konsumen terhadap jajanan tradisional dan modern berdasarkan usia

\begin{tabular}{|c|c|c|c|c|c|c|}
\hline \multirow{2}{*}{ Jajanan yang Lebih Disukai } & \multicolumn{4}{|c|}{ Usia (Tahun) } & \multirow{2}{*}{ Total } & \multirow{2}{*}{ Persentase (\%) } \\
\hline & 13-17 & $18-25$ & $26-35$ & $\geq 36$ & & \\
\hline $\begin{array}{l}\text { Tradisional } \\
\text { Modern }\end{array}$ & $\begin{array}{c}18 \\
7\end{array}$ & $\begin{array}{l}25 \\
11\end{array}$ & 12 & 24 & $\begin{array}{l}79 \\
21\end{array}$ & $\begin{array}{l}79.00 \\
21.00\end{array}$ \\
\hline Total & 25 & 36 & 14 & 25 & 100 & 100.00 \\
\hline
\end{tabular}

Mayoritas konsumen tergolong sering mengonsumsi jajanan tradisional, sehingga terdapat peluang bagi pelaku usaha untuk menjual jajanan tradisional. Sebanyak $79 \%$ konsumen lebih menyukai jajanan tradisional, dengan alasan rasanya enak dan khas, harganya terjangkau, bahan bakunya alami, tanpa pengawet, sekaligus melestarikan budaya.

\section{DAFTAR PUSTAKA}

Adnan. 2018. Pengaruh perilaku konsumen terhadap keputusan pembelian susu Morinaga di Kota Lhokseumawe. J Visioner Strategis 7(2): 1-9.

Amelia D. 2017. Perancangan desain kemasan peppy's snack Surabaya. J Seni Rupa 5(3): 584-590.

Aprile MC, Caputo V, Nayga RM Jr. 2012. Consumers' valuation of food quality labels: The case of the European geographic indication and organic farming labels. Int J Consum Stud 36(2): 158165. DOI: 10.1111/j.1470-6431.2011.01092.x.

Balentic JP, Babic J, Jozinovic A, Ackar D, Milicevic B, Begovic BM, Subaric D. 2018. Production of third generation snacks. Croat J Food Sci Technol 10(1): 98-105. DOI: 10.17508/CJFST.2018.10.1.04.

Balogh P, Békési D, Gorton M, Popp J, Lengyel P. 2016. Consumer willingness to pay for traditional food products. Food Policy 61(2016): 176-184. DOI: 10.1016/j.foodpol.2016.03.005.

Blum LS, Mellisa A, Sari EK, Yusadiredja IN, van Liere M, Shulman S, Izwardy D, Menon R, Tumilowicz A. 2019. In-depth assessment of snacking behaviour in unmarried adolescent girls 16-19 years of age living in urban centres of Java, Indonesia. Matern Child Nutr 15(4): e12833. DOI: 10.1111/mcn. 12833.

[BPS] Badan Pusat Statistik Kabupaten Pekalongan. 2020. Kabupaten Pekalongan dalam Angka. Pekalongan (ID): BPS Kabupaten Pekalongan.

Casini L, Contini C, Romano C, Scozzafava G. 2016. New trends in food choice: What impact on sustainability of rural areas? Agric Agric Sci Proc 8: 141147. DOI: 10.1016/j.aaspro.2016.02.019.

Francisca, Palupi NS, Faridah DN. 2016. Persepsi konsumen dalam menentukan keputusan pembelian produk minuman dengan klaim kurang gula. J Mutu Pangan 3(1): 50-57.

Favalli S, Skov T, Byrne DV. 2013. Sensory perception and understanding of food uniqueness: From the traditional to the novel. Food Res Int 50 (1):176188. DOI: 10.1016/j.foodres.2012.10.007.

Forbes SL, Kahiya E, Balderstone C. 2016. Analysis of snack food purchasing and consumption behavior. J Food Prod Mark 22(1): 65-88. DOI: 10.1080/ 10454446.2014.949992.

Giantara MS, Santoso J. 2014. Pengaruh budaya, sub budaya, kelas sosial, dan persepsi kualitas terhadap perilaku keputusan pembelian kua tradisional oleh mahasiswa di Surabaya. J Hospitality Manajemen Jasa 2(1): 111-126.

Haryanto B, Purwanto D, Dewi AS, Cahyono E. 2019. How does the type of product moderate consumers' buying intentions towards traditional foods? (Study of consumer behavior in Indonesia). J Asia Bus Stud 13(4): 525-542. DOI: 10.1108/JABS-10-2018-0299.

Khairullah M. 2020. Analisis pengaruh variabel demografis terhadap minat beli jajanan tradisional di Kecamatan Kraton Yogyakarta. Indonesian J Islamic Economics Bus 5(1): 15-31.

Komalasari E, Widiawati D. 2020. Tingkat kepatuhan pedagang pangan jajanan terhadap cara produksi pangan yang baik. Jurnal Al-Azhar Indonesia Seri Sains Teknol 5(3): 130-135. DOI: 10.36722/sst. v5i3.375.

Noviadji BR. 2014. Desain kemasan tradisional dalam konteks kekinian. Artika J Fakultas Desain 1(1): 1021. DOI: 10.34148/artika.v1i1.24.

Siregar S. 2017. Metode Penelitian Kuantitatif. Ed ke-4. Jakarta (ID): Kencana.

Sidhartha I, Sidh R. 2014. Pengukuran persepsi manfaat dan persepsi kemudahan terhadap sikap serta dampaknya atas penggunaan ulang online shopping pada e-commerce. J Computech Bisnis 8(2): 92-100.

Sumarwan U, Tjiptono F. 2018. Strategi Pemasaran dalam Perspektif Perilaku Konsumen. Bogor (ID): IPB Press.

Yulianti U. 2011. Faktor-faktor yang mempengaruhi konsumen dalam pembelian makanan jajan tradisional di Kota Malang. J Manajemen Bisnis 1(1): 7-20. DOI: 10.22219/jmb.v1i1.1318.

Zbib IJ, Wooldridge BR, Ahmed ZU, Benlian S. 2010. Selection criteria of Lebanese consumer in the global snack food industry: Country of origin perception. J Consum Mark 27(2): 139-156. DOI: $10.1108 / 07363761011027240$.

JMP-07-21-08-Naskah diterima untuk ditelaah pada 7 Januari 2021. Revisi makalah disetujui untuk dipublikasi pada 26 Februari 2021. Versi Online: http://journal.ipb.ac.id/index.php/jmpi 